\title{
Levantamento de Gesneriaceae Rich. \& Juss. no Núcleo Curucutu, Parque Estadual da Serra do Mar, São Paulo, SP, Brasil
}

\author{
Paulo Affonso ${ }^{1,3}$, Cátia Takeuchi² e Rodrigo Keithy Nakano ${ }^{1}$
}

Recebido: 16.04.2013; aceito: 22.05.2014

\begin{abstract}
Survey of the Gesneriaceae Rich. \& Juss. in Núcleo Curucutu, Parque Estadual da Serra do Mar, São Paulo, São Paulo State, Brazil). This work consisted of a floristic survey and taxonomical study of the Gesneriaceae Rich. \& Juss. in Núcleo Curucutu, Parque Estadual da Serra do Mar, São Paulo, São Paulo State, Brazil. Keys of identification, morphological descriptions, illustrations, geographic distribution, and phenology are presented. The family is represented in the area by four genera and seven species: Besleria selloana Klotzsch \& Hanst., Codonanthe gracilis (Mart.) Hanst., Nematanthus bradei (Handro) Chautems, N. gregarius D.L. Denham, N. maculatus (Fritsch) Wiehler, N. wettsteinii (Fritsch) H.E. Moore, and Sinningia elatior (Kunth) Chautems. Nematanthus wettsteinii and $N$. maculatus were recorded for the first time in the study area. Keyworks: Besleria, Codonanthe, Nematanthus, Sinningia, taxonomy
\end{abstract}

RESUMO - (Levantamento de Gesneriaceae Rich. \& Juss. no Núcleo Curucutu, Parque Estadual da Serra do Mar, São Paulo, SP, Brasil). Este estudo consistiu no levantamento florístico e estudo taxonômico de Gesneriaceae Rich. \& Juss. no Núcleo Curucutu, Parque Estadual da Serra do Mar, São Paulo, SP, Brasil. O trabalho consta de chaves de identificação, descrições morfológicas, ilustrações, dados de distribuição geográfica e de fenologia. A família está representada na área por quatro gêneros e sete espécies: Besleria selloana Klotzsch \& Hanst., Codonanthe gracilis (Mart.) Hanst., Nematanthus bradei (Handro) Chautems, N. gregarius D.L. Denham, N. maculatus (Fritsch) Wiehler, N. wettsteinii (Fritsch) H.E. Moore e Sinningia elatior (Kunth) Chautems. Nematanthus wettsteinii e N. maculatus foram registradas pela primeira vez na área de estudo.

Palavras-chave: Besleria, Codonanthe, Nematanthus, Sinningia, taxonomia

\section{Introdução}

Gesneriaceae inclui de 150-160 gêneros e cerca de 3.200 espécies com distribuição predominantemente pantropical (Weber \& Skog 2007 [em diante]), sendo que a radiação ocorreu para todos os biomas da América Tropical e foi acompanhada por uma grande diversificação fenotípica e ecológica (Perret et al. 2013). O principal centro de diversidade da família localiza-se no noroeste da América do Sul (da Colômbia ao Equador) e na América Central (Chautems 1991, Perret et al. 2013).

O Brasil possui 29 gêneros e 214 espécies, sendo que a região sudeste constitui o seu centro secundário, com 133 espécies que estão concentradas principalmente na Mata Atlântica. O Estado de São
Paulo abriga sete gêneros e 57 espécies (Araújo \& Chautems 2013).

Trata-se de uma família monofilética (Smith 1996, Smith et al. 1997) que desenvolveu ao longo da sua evolução complexas formas florais, resultando em um grande desafio para a circunscrição dos gêneros e para o estabelecimento das relações evolutivas entre os táxons. Neste aspecto, os trabalhos de filogenia molecular têm se mostrado um grande aliado, principalmente na tribo Episcieae que é a mais diversificada dentro das Gesneriaceae neotropicais, em número de espécies e estrutura morfológica (Clark et al. 2012).

A família compreende ervas, subarbustos, arbustos - terrestres ou epifíticos, com ou sem rizomas ou tubérculos - ou árvores de pequeno

1. Universidade de Santo Amaro, Faculdade de Biologia, Rua Prof. Enéas de Siqueira Neto, 340, 04829-300 São Paulo, SP, Brasil

2. Instituto de Botânica, Av. Miguel Estéfano, 3687, 04101-902 São Paulo, SP, Brasil

3. Autor para correspondência: pauloaffonso.botanico@gmail.com 
porte; caule herbáceo ou lenhoso, ereto, escandente ou pendente. As folhas são geralmente simples, opostas a raramente rosuladas ou verticiladas, em geral pecioladas, com venação peninérvia, sem estípulas. A inflorescência é axilar ou terminal, em geral cimosa ou com flores solitárias, comumente vistosas, bissexuadas, diclamídeas, zigomorfas, raro actinomorfas, corola tubulosa, às vezes gibosa, cálice pentâmero, estames (2-)4(-5), em geral ligeiramente didínamos, epipétalos, anteras unidas aos pares ou todas juntas, raro livres, rimosas, às vezes poricidas; disco nectarífero frequente; estilete simples, ovário súpero, semi-ínfero ou ínfero, bicarpelar, unilocular com placentação parietal, ou raramente bilocular com placentação axial, pluriovulado. Fruto cápsula ou baga. Sementes numerosas e pequenas, dispersas pelo vento, água (chuva), aves e formigas, endosperma presente ou ausente (Chautems 2003, Weber \& Skog 2007 [em diante]).

Gesneriaceae possui grande valor ornamental, devido às suas flores vistosas, destacando-se as espécies dos gêneros Nematanthus Schrad., Sinningia Nees. e Saintpaulia H. Wendl. (Chautems 2003, Souza \& Lorenzi 2012).

O presente trabalho faz parte do estudo da Flora do Núcleo Curucutu que a Universidade de Santo Amaro e o Herbário PMSP desenvolvem em parceria. Várias famílias já foram ou vêm sendo estudadas, dentre as quais: Melastomataceae (Silva \& Affonso 2005, Rodrigues Lima \& Affonso 2010), Iridaceae (Takeuchi et al. 2008), Gentianaceae (Pscheidt \& Affonso 2008), Ericaceae (Takeuchi \& Affonso 2009) e Orchidaceae (Rosa \& Affonso 2009).

Com o objetivo de desenvolver o estudo taxonômico das Gesneriaceae do Núcleo Curucutu, foram realizadas coletas, identificações, descrições e a confecção de chaves de identificação dos gêneros e espécies, contribuindo assim para o conhecimento da flora local e do Estado de São Paulo.

\section{Material e métodos}

O estudo foi realizado no Núcleo Curucutu situado entre 50 e $870 \mathrm{~m}$ de altitude, abrangendo os municípios de Itanhaém, Juquitiba, Mongaguá e São Paulo, com uma área de aproximadamente 3.000 ha (Garcia \& Pirani 2005, IF 2013). A vegetação é constituída por um mosaico de formações florestais e campestres, cobertas frequentemente pela neblina. A importância da preservação e conhecimento sobre esta área de estudo é sustentada por constituir um dos últimos remanescentes da Mata Atlântica nas imediações da capital paulista, além de abrigar as nascentes dos rios Capivari e Embu-Guaçu, tributários da Represa Guarapiranga que abastece a região metropolitana de São Paulo, e parte do rio Mambu que abastece Itanhaém (Garcia \& Pirani 2005).

Os espécimes examinados encontram-se depositados nas coleções científicas da Universidade de Santo Amaro e do Herbário PMSP, sendo provenientes de coletas realizadas anteriormente e durante o desenvolvimento deste trabalho. A herborização seguiu a metodologia usual descrita por Fidalgo \& Bononi (1989). As ilustrações foram confeccionadas com estereomicroscópio acoplado à câmara clara e cobertas à nanquim pelo ilustrador Klei Rodrigo de Sousa.

Para as análises e identificações das amostras foram consultadas a literatura especializada (Chautems 2000, 2003, Araújo et al. 2005), as obras contendo as descrições originais e as coleções de Gesneriaceae dos herbários visitados, PMSP, SP, SPF e SPSF (siglas de acordo com Thiers [continuamente atualizado]). Os dados de floração e frutificação foram obtidos nos rótulos das exsicatas, em observações de campo e em literatura especializada. A terminologia morfológica empregada foi definida em Harris \& Harris (1994) e Gonçalves \& Lorenzi (2007). Para as medidas de comprimento e altura da giba, foram utilizados os materiais de exsicatas; para altura mediu-se no sentido vertical do lado ventral ao dorsal da giba; para comprimento mediu-se no sentido horizontal do final da parte tubuloso-cilíndrica da corola em direção à fauce. A definição do fruto de Nematanthus utilizada condiz com os trabalhos de Chautems (2003) e Araújo et al. (2005).

\section{Resultados e Discussão}

Chave de identificação dos gêneros de Gesneriaceae do Núcleo Curucutu

1. Subarbustos epifíticos

2. Corola tubuloso-ventricosa, amarela, alaranjada, rosada, vermelha ou vinácea; anteras rimosas; fruto cápsula ..... 3. Nematanthus

2. Corola infundibuliforme, alva; anteras poricidas; fruto baga 2. Codonanthe

1. Ervas a subarbustos terrestres 
3. Ervas até $75 \mathrm{~cm}$ alt.; folhas 3 -verticiladas; lâminas com margem crenada e base obtusa; inflorescência em pseudoracemo, terminal; sépalas verdes; corola vermelha; nectário formado por 5 glândulas, 2 dorsais maiores e unidas; fruto cápsula ........ 4. Sinningia

3. Subarbustos 1-1,5 m alt.; folhas opostas; lâminas com margem denteada e base cuneada; inflorescência em cimeira, axilar; sépalas amarelas; corola alva; nectário anular; fruto baga 1. Besleria

1. Besleria selloana Klotzsch \& Hanst. in Mart., Fl. bras. 8(1): 398. 1864.

Figura $1 \mathrm{c}-\mathrm{d}$

Subarbustos 1-1,5 m alt., terrestres. Caule ereto, entrenós $0,5-1 \mathrm{~cm}$, cilíndrico-achatado a quadrangular, tomentoso a glabrescente, com tricomas simples. Folhas anisófilas, opostas, pecioladas; pecíolo 3,5-5,5 cm compr., tomentoso; lâmina $15,5-25 \times 5,5-8 \mathrm{~cm}$, elíptica a ovada, membranácea, base cuneada, ápice acuminado, margem denticulada e esparsa ou irregularmente denteada, face adaxial tomentosa a glabrescente, face abaxial pubérula, tomentosa nas nervuras, verde nas duas faces, borda verde, 13-14 pares de nervuras secundárias evidentes. Inflorescência axilar, cimosa, 1-3 flores não ressupinadas, pedúnculo $2,5-3 \mathrm{~cm}$ compr., amarelo a vináceo, tomentoso; pedicelo 2,5-2,7 cm compr., tomentoso; 1-2 bractéolas por flor, 2-4 mm compr.; sépalas 1-1,2 × ca. 0,4 cm, papiráceas, amarelas, pubescentes, pubérulas no ápice, obovado-oblongas, ápice obtuso-arredondado, eretas, margem inteira; corola 1,4-2,2 cm compr., tubulosa-ventricosa, parte tubulosa 1,2-1,9 cm compr., giba pouco pronunciada na porção mediana do tubo, ca. $0,5 \times 0,1 \mathrm{~cm}$, alva, glabrescente, lobos 2-3 mm compr., livres entre si, concolores, patentes; estames 4, filetes glabros, anteras unidas em retângulo, inclusas, rimosas; nectário anular; ovário $4 \mathrm{~mm}$ compr., súpero, tricomas glandulares diminutos e esparsos, estilete ca. $8 \mathrm{~mm}$ compr., com tricomas glandulares diminutos e esparsos, estigma incluso. Baga 1-2,1 × 1,1-1,5 cm, verde quando imatura, globosa, tricomas simples esparsos, base do estilete persistente na maturidade, $0,4-0,7 \mathrm{~cm}$ compr.; sementes irregularmente angulosas, castanhas, estriadas.

O gênero Besleria possui cerca de 200 espécies distribuídas na região neotropical (Lopes et al. 2007). No Brasil está representado por 21 espécies, sendo sete endêmicas. O Estado de São Paulo apresenta três espécies (Araújo \& Chautems 2013).

Besleria selloana é endêmica do Brasil, ocorrendo nos Estados de São Paulo e do Paraná (Chautems 2003, Araújo \& Chautems 2013). No Núcleo Curucutu é conhecida por apenas duas coletas realizadas em ambiente florestal úmido. Floresceu em outubro e novembro.

Os caracteres encontrados nos materiais examinados deste trabalho foram compatíveis com aqueles descritos para esta espécie na diagnose original e por Chautems (2003). Entretanto, o número de flores por inflorescência (2-3 flores) encontrados nos materiais analisados do Núcleo Curucutu não corroborou com o número (6-12 flores) obtido por Chautems (2003). A análise do número de flores por inflorescência poderia induzir a identificação deste material como B. umbrosa, mas a avaliação das imagens do tipo desta espécie não corrobora com a chave descrita por Chautems (2003). Por outro lado, a avaliação da forma e ápice das sépalas, ovado-lanceolado e agudo, para B. umbrosa, e obovado-oblonga e obtuso-arredondado em $B$. selloana, é suficiente para diferenciá-las.

Besleria selloana distingue-se facilmente das demais espécies estudadas pelo hábito de subarbusto e por ser a única a apresentar inflorescência em cimeira axilar, sépalas amarelas e o nectário floral anular.

Material examinado: BRASIL. São PAULo: São Paulo, Trilha do Rio Branco, 30-X-1998, fl., R.J.F. Garcia $1663 \&$ M. Alonso (PMSP). Trilha da Captação da Água, 26-XI-1999, fl., T. Forti 30 et al. (PMSP).

Material adicional examinado: BRASIL. S̃̃o PAULO: Miracatu, Fazenda Iteré́, Serra de Paranapiacaba, 19-IV-1994, fr., J.R. Pirani \& R.F.J. Garcia 3115 (SP); Parque Estadual de Jarupará, 6-IX-1995, fl., J.B. Baitello 802 \& O.T. Aguiar (PMSP); Mogi das Cruzes, Serra do Mar, 28-VII-1983, fl., M. Kirizawa 1017 et al. (SP); Picinguaba, Parque Estadual da Serra do Mar, 22-IX-1988, fl., O.T. Aguiar 263 (SPSF); Salesópolis, Estação Biológica de Boracéia, fl., R. Simão-Bianchini 485 et al. (SP); Santos, Área da Santa Casa de Misericórdia, 27-VIII-2007, fl., R.J.F. Garcia 3061 et al. (PMSP).

2. Codonanthe gracilis (Mart.) Hanst., Linnaea 26: 209. 1854

Figura $1 \mathrm{a}-\mathrm{b}$

Subarbustos epifíticos. Caule pendente, entrenós 1,5-6,5 cm, cilíndrico, glabro ou com tricomas simples 


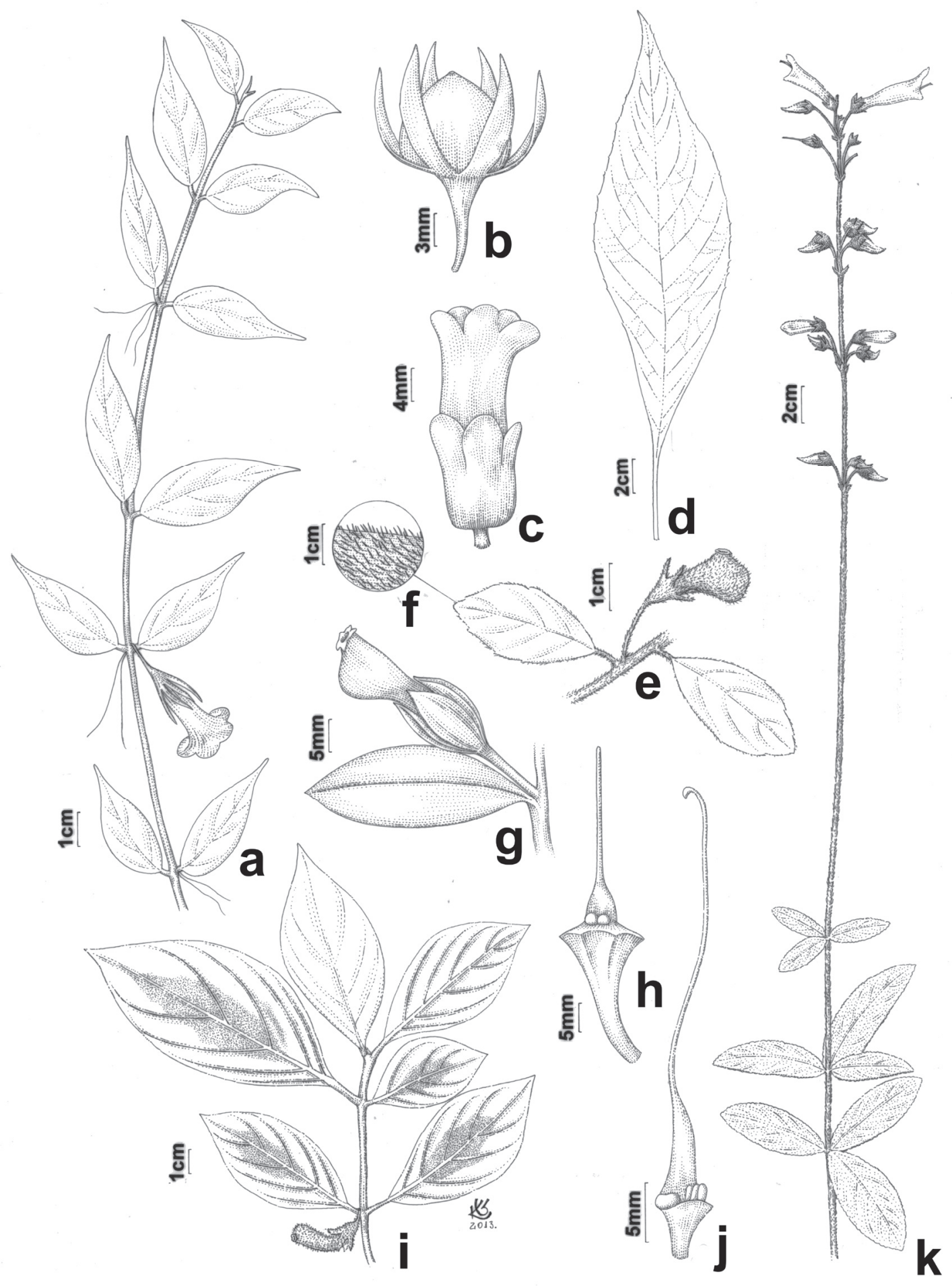

Figura 1. a-b. Codonanthe gracilis. a. Ramo com flor. b. Fruto. c-d. Besleria selloana. c. Flor. d. Folha. e-f. Nematanthus bradei. e. Porção de um ramo com flor. f. Detalhe do indumento. g-h. Nematanthus gregarius. g. Porção de um ramo com flor. h. Gineceu e glândulas nectaríferas. i. Nematanthus maculatus. Ramo com flor. j-k. Sinningia elatior. j. Gineceu e glândulas nectaríferas. k. Hábito.

Figure 1.a-b. Codonanthe gracilis. a. Branch with flower. b. Fruit. c-d. Besleria selloana. c. Flower. d. Leaf. e-f. Nematanthus bradei. e. Portion of a branch with flower. f. Detail of indumentum. g-h. Nematanthus gregarious. g. Portion of a branch with flower. h. Gynoecium and nectariferous glands. i. Nematanthus maculatus. Branch with flower. j-k. Sinningia elatior. j. Gynoecium and nectariferous glands. k. Habit. 
esparsos, com raízes adventícias. Folhas anisófilas, opostas, pecioladas; pecíolo 1-3 mm compr., esparsamente piloso; lâmina 2-6,2 × 0,9-2,6 cm, ovado-elíptica a ovada, crassa, base obtusa a arredondada, ápice acuminado, margem inteira, face adaxial glabra, verde, face abaxial glabra ou esparsamente pilosa, verde, às vezes vinácea nos dois terços basais, borda-verde, nervuras secundárias pouco evidentes. Flores 1-2 por axila, não ressupinadas; pedicelo 4-8 $\mathrm{mm}$ compr., esparsamente piloso; sépalas 10-17 × 2-5 mm, papiráceas, verdes, com tricomas simples esparsos, lanceoladas a ovallanceoladas, ápice agudo, eretas, margem inteira; corola 2-2,2 cm compr., infundibuliforme, parte tubuloso-cilíndrica 10-12 mm compr., giba pouco pronunciada na porção basal do tubo, ca. $0,4 \times 0,1 \mathrm{~cm}$, alva, fauce amarelada, com pontuações castanhas a vináceas e tricomas glandulares nos dois terços superiores, lobos 3-7 mm compr., livres entre si, concolores, patentes; estames 4, filetes glabros, anteras unidas em retângulo, inclusas, poricidas; nectário formado por uma glândula dorsal anexa, 2-lobada; ovário-1-2 mm compr., súpero, glabro, estilete 7-14 mm compr., glabro, estigma incluso. Baga 8-11 × 8-9 mm, alaranjada, obovada, glabra, base do estilete não persistente na maturidade; sementes elípticas, castanhas, estriadas.

Material examinado: BRASIL. São PAULO: São Paulo, Trilha do Mirante, 20-XII-1996, fl., R.J.F. Garcia 989 et al. (PMSP); Estrada da Entrada, 19-X-1997, fl., R.J.F. Garcia 1326 et al. (PMSP, UNISA); Trilha do Rio Embu-Guaçú, fl., 15-XI-1997, J.V. Coffani-Nunes et al. 162 (PMSP); Trilha do Mirante, 15-XII-1997, fl. e fr., R.J.F. Garcia 1410 et al. (PMSP); Trilha do Marco, 16-V-1998, fl., fr., E.H. Silva 88 et al. (PMSP, UNISA); Estrada da Entrada, 28-I-1999, fl.e fr., L.C.Q.M.P. Sampaio 155 et al. (PMSP, UNISA); Trilha do Lago, 25-II-1999, fr., C.M. Izumizawa 143 et al. (PMSP, UNISA); Trilha do Mirante, fl., fr., 21-XII-1999, P. Affonso 432 et al. (PMSP); Trilha da Bica, fl., 24-XI-2004, P. Affonso 748 et al. (UNISA); Trilha do Mirante, 16-XII-2004, fl., P. Affonso 772 et al. (UNISA); Trilha da Entrada, fr., 15-III-2006, P. Affonso 926 et al. (UNISA); Trilha do Mirante, fl., 28-X-2006, P. Affonso 947 et al. (UNISA); Trilha da Bica, fl., 28-X-2006, P. Affonso 948 et al. (UNISA); Trilha do Japonês, fl., 28-X-2006, Nakano $1 \&$ C. Takeuchi (UNISA); Trilha da Entrada, fl., 11-XII-2006, Nakano 4 (UNISA); Estrada da Entrada, fl. 31-III-2009, P. Affonso 1115 et al. (UNISA).
Material adicional examinado: BRASIL. S̃̃o Paulo: Santo André, 26-VI-2001, fl. e fr., C. Moura \& J. Clementino s.n. (SPSF28319); Salesópolis, Estação Biológica de Boracéia, 27-IV-1966, fl., J. Mattos 13476 (SP); Ubatuba, Núcleo Picinguaba, fl., 29-VIII-1994, M.A. de Assis 404 et al. (SP).

O gênero Codonanthe possui cerca de 20 espécies, todas presentes na região neotropical (Chautems 2003), das quais 11 ocorrem no Brasil, na Mata Atlântica e na Amazônia. O Estado de São Paulo abriga quatro espécies (Araújo \& Chautems 2013).

Codonanthe gracilis é endêmica do Brasil e possui distribuição desde o Estado da Bahia, estendendo-se até o Rio Grande do Sul. Trata-se de uma espécie restrita à Mata Atlântica onde é frequentemente coletada (Chautems 2000, 2003, Araújo \& Chautems 2013).

No Núcleo Curucutu foi encontrada com frequência em ambientes úmidos onde forma pequenas populações. A floração ocorre durante todo o ano e a frutificação de outubro a março, corroborando com os dados fenológicos apresentados por Chautems (2000, 2003).

Dentre as espécies estudadas, possui maior afinidade com as espécies de Nematanthus em função do hábito epifítico e o nectário floral formado por uma glândula dorsal anexa e 2-lobada. Entretanto, é claramente distinta por apresentar a corola tubulosaventricosa e alva, anteras poricidas e pelo fruto do tipo baga alaranjado.

Os caracteres encontrados nos materiais examinados deste trabalho foram compatíveis com aqueles descritos para esta espécie na diagnose original, bem como nos trabalhos de Hanstein (1864) na Flora brasiliensis e de Chautems (2000, 2003), exceto pelo indumento do pedicelo, que é esparsamente piloso nos exemplares da área de estudo e glabro nos estudos citados.

\section{Nematanthus Schard.}

Subarbustos epifíticos. Caule escandente ou pendente, glabro, hirsuto ou pubérulo, às vezes glabrescente, com raízes adventícias. Folhas anisófilas ou não, opostas, pecioladas; lâmina geralmente crassa, margem inteira ou serreada. Flores 1-3 por axila, ressupinadas ou não; pediceladas; sépalas ovadoelípticas, elípticas, lanceoladas ou lineares, eretas ou levemente revolutas, margem inteira ou não; corola tubuloso-ventricosa, com base cilíndrica alargada em giba pronunciada na porção apical do tubo, em posição 
horizontal em relação ao ramo, amarela, alaranjada, rosada, vermelha ou vinácea, lobos livres entre si, concolores ou não, eretos a patentes; estames 4 , filetes glabros, anteras unidas em retângulo, inclusas, rimosas; nectário formado por uma glândula dorsal anexa, 2-lobada; ovário súpero, estigma incluso. Cápsula carnosa loculicida, 2-valvar, ovóide-cônica, base do estilete não persistente na maturidade; sementes elípticas, castanhas, estriadas.

Nematanthus possui 32 espécies, das quais 31 são endêmicas do Brasil, distribuídas desde o Estado de Pernambuco até o Rio Grande do Sul, ocorrendo principalmente na Mata Atlântica, mas ocorre também na Amazônia e no Cerrado. No Estado de São Paulo foram registradas 20 espécies (Araújo \& Chautems 2013).

No Núcleo Curucutu as espécies foram encontradas no interior da mata, em ambientes úmidos e sombreados. Os frutos destas espécies, especialmente de $N$. bradei e de $N$. gregarius foram raramente observados nos materiais da área de estudo e nos exemplares adicionais analisados nos herbários visitados.

Chave de identificação das espécies de Nematanthus do Núcleo Curucutu

1. Lâminas com mácula vinácea na face abaxial; flores ressupinadas; sépalas com margem serreada; corola hirsuta 3.3. N. maculatus

1. Lâminas sem mácula vinácea na face abaxial; flores não ressupinadas; sépalas com margem inteira; corola glabra, pubérula a pubescente

2. Folhas anisófilas; lâminas pubescentes em ambas as faces, margem esparsamente serreada; corola com giba 1,1-1,4 × 1,1-1,3 cm ...

2. Folhas isófilas; lâminas esparsamente pilosas ou pubérulas na face abaxiale glabras na face adaxial, margem inteira; corola com giba $0,6-1,1 \times 0,6-1,1 \mathrm{~cm}$.

3. Lâminas 1,2-3,2 × 0,8-1,6 cm; sépalas $10-15 \times 4-6 \mathrm{~mm}$, verdes na base e alaranjadas no ápice ou totalmente alaranjada, coriáceas, glabras; corola glabra, lobos concolores ....... 3.2. N. gregarius 3.Lâminas $0,8-1,7 \times 0,5-0,8 \mathrm{~cm}$; sépalas 2-3 $\times$ ca. $1 \mathrm{~mm}$, verdes, membranáceas, pubérulas; corola pubérula, lobos discolores ...... 3.4. N. wettsteinii
3.1. Nematanthus bradei (Handro) Chautems, Candollea 39(1): 297. 1984.

Figura 1 e-f

Caule com entrenós $0,5-3,6 \mathrm{~cm}$, cilíndrico, hirsuto a glabrescente. Folhas anisófilas; pecíolo 4-10 mm compr., pubescente; lâmina 1,5-4,2 × ca. 2,2 cm, ovado-elíptica, base obtusa a levemente cuneada, ápice agudo, margem esparsamente serreada, pubescente e verde nas duas faces, borda verde, 3-4 pares de nervuras secundárias evidentes. Flores 1 por axila, não ressupinadas; pedicelo 5-19 mm compr., pubescente; sépalas 6-12 × 3-4 mm, coriáceas, verdes, hirsutas com maior concentração de tricomas na base, ovadoelípticas, ápice acuminado, eretas, margem inteira; corola 1,5-2,4 cm compr., parte tubuloso-cilíndrica 5-11 mm compr., giba pronunciada na porção mediana superior do tubo, 1,1-1,4 × 1,1-1,3 cm, vermelho-alaranjada, pubescente, lobos 1,5-2 mm compr., concolores, patentes; ovário ca. $3 \mathrm{~mm}$ compr., pubescente, estilete ca. $8 \mathrm{~mm}$ compr., pubescente na base a glabrescente no ápice. Cápsula ca. $13 \times 14 \mathrm{~mm}$, valvas verdes, pubérula.

Material examinado: BRASIL. São PAULO: São Paulo, Trilha do Campo, 18-XII-1996, fl., R.J.F. Garcia 937 et al. (PMSP, SPF, UNISA); Trilha do Mirante, 21-XII-1997, fl., R.J.F. Garcia 1357 et al. (PMSP, UNISA); Borda da Matinha, 14-XII-1997, fl., R.J.F. Garcia 1453 et al. (PMSP, UNISA); Trilha da primeira casa abandonada, 21-XII-1999, fl., R.J.F. Garcia 1851 et al. (PMSP, UNISA); Trilha da Mata, 30-XI-2001, fl., M.A. Pena 4 et al. (PMSP); Trilha do Mirante, 16-XII-2004, fl., P. Affonso 771 et al. (UNISA); Trilha do Japonês, 28-X-2006, fl., Nakano 2 \& C. Takeuchi (UNISA); Trilha do Mirante, 11-XII-2006, fl., Nakano 7 (UNISA); Trilha do Mirante, 14-XI-2009, fl., P. Affonso 1175 et al. (UNISA). Trilha da Bica, 19-I-2009, fl., P. Affonso 1104 et al. (UNISA).

Material adicional examinado: BRASIL. São PAULo: Biritiba Mirim, 25-IX-1986, fl., A. Custódio Filho 2627 (SPSF); Itanhaém, Fazenda São Luís, 8-X-1995, fl., fr., V.C. Souza 9238 et al. (SP); São Paulo, Capivari, 13-IX-1994, fl., S.A.P. Godoy 224 et al. (PMSP); Ubatuba, 12-XI-1993, fl., R. Goldenberg 29843 et al. (SP, SPF).

Nematanthus bradei é endêmica do Estado de São Paulo (Chautems 2003, Araújo \& Chautems 2013), com distribuição restrita a Serra de Cubatão entre 700 e 900 m de altitude, na Mata Atlântica (Chautems 2003). 
No Núcleo Curucutu foi observado frequentemente formando pequenas populações, inclusive sobre a serapilheira. Floresceu de novembro a dezembro, raramente em janeiro, corroborando com os dados fenológicos apresentados por Chautems (2003). A frutificação foi observada apenas uma vez, em novembro.

Nematanthus bradei diferencia-se facilmente das demais espécies estudadas do gênero por apresentar o caule subtetragonal, lâminas com tricomas densos em ambas as faces e a corola com a giba comparativamente pronunciada.

3.2. Nematanthus gregarius D.L. Denham, Baileya 19: 126. 1974.

Figura $1 \mathrm{~g}-\mathrm{h}$

Caule com entrenós 0,5-4,0 cm, cilíndrico, glabro. Folhas isófilas; pecíolo 1-3 mm compr., esparsamente piloso; lâmina 1,2-3,2 × 0,8-1,6 cm, elíptica a ovada, base cuneada a obtusa, ápice acuminado a obtuso, margem inteira, face adaxial glabra, face abaxial esparsamente pilosa, principalmente na nervura central, verde nas duas faces, borda alaranjada, nervuras secundárias não evidentes. Flores 1-3 por axila, não ressupinadas; pedicelo $4-13 \mathrm{~mm}$ compr., glabro; sépalas 10-15 × 4-6 mm, coriáceas, verdes na base e alaranjadas no ápice ou totalmente alaranjadas, glabras, elípticas, ápice agudo a obtuso, eretas, margem inteira; corola 1,6-2,4 cm compr., parte tubuloso-cilíndrica 5-8 $\mathrm{mm}$ compr., giba pronunciada na porção mediana superior do tubo, 0,9-1,1 × 0,8-1,1 cm, amarela ou laranja, glabra, lobos $2 \mathrm{~mm}$ compr., com estrias vermelhas na junção entre si, concolores, patentes; ovário ca. $5 \mathrm{~mm}$ compr., glabro, estilete ca. $15 \mathrm{~mm}$ compr., glabro. Cápsula 5-7 × 2-6 mm, valvas amarelas, glabra.

Material examinado: BRASIL. São PAulo: São Paulo, Trilha do Mirante, 16-XII-1995, fl., S.A.P. Godoy 748 (PMSP); Trilha do Mirante, 8-VII-1997, fl., R.J.F. Garcia 1205 et al. (PMSP, UNISA); Trilha do Mirante, 16-V-1998, fl., M.A.S. Mayworm 120 et al. (UNISA); Trilha do Mirante, 20-IX-1998, fl., J.R. Pirani 4441 (SPF); Trilha da Bica, 6-VII-2000, fl., P. Affonso 459 et al. (UNISA); Trilha do Mirante, 17-08-2001, fl., P. Affonso 539 et al. (UNISA). Trilha do Mirante, 25-06-2003, fl., P. Affonso 627 et al. (UNISA); Trilha do Mirante, 25-09-2006, fl., P. Affonso 933 et al. (UNISA); Trilha do Mirante, 25-09-2006, fl., P. Affonso 936 et al. (UNISA); Trilha da Captação d'água, 25-09-2006, fl., P. Affonso 939 et al. (UNISA); Estrada da Entrada, 11-XII-2006, fl., Nakano 5 (UNISA); Trilha da Entrada, 11-XII-2006, fl., Nakano 6 (UNISA); Trilha do Rio Embu-Guaçu, 28-V-2007, P. Affonso 991 et al. (UNISA); Estrada da Entrada, 25-VII-2008, fl., C. Takeuchi 33 et al. (UNISA); Trilha do Rio Embu-Guaçú, 29-VII-2009, fl., $P$. Affonso 1147 et al. (UNISA); Mata do Heliporto, 16-IX-2009, fl., fr., P. Affonso 1158 et al. (UNISA); Trilha do Mirante, 14-11-2009, fr., P. Affonso 1176 et al. (UNISA); Trilha da Entrada, 21-XII-2009, fr. P. Affonso 1181 et al. (UNISA); Mata do Heliporto, 16-IX-2009, fl., fr., P. Affonso 1158 et al.(UNISA); Trilha do Mirante, 15-V-2010, fl. P. Affonso 1229 et al. (UNISA).

Material adicional examinado: BRASIL. São PAULO: Bertioga, Loteamento Morada da Praia, 16-10-1992, fl., M. Kirizawa 2778 et al. (SP); Cunha, 13-XII-1998, fl., J.P. Souza 828 et al. (SP, SPF); Salesópolis, Est. Biológica de Boracéia, 4-IX-1994, fl., L. Rossi 1638 et al. (SPF); São Miguel do Arcanjo, Parque Estadual Carlos Botelho, fl., 22-IX-1992, M. Sugiyama \& M. Kirizawa 1016 (SP, SPSF); São Paulo, Est. Biológica Alto da Serra, 2-III-1932, fl., W. Hoehne s.n. (SPF); São Paulo, Jardim Novo Parelheiros, Estrada do Marsilac, clareira, 14-IX-1994, fl., S.A.P. Godoy 268 et al. (PMSP).

Segundo Chautems (2003), Nematanthus gregarius é uma espécie ornamental que ocorre apenas na Serra do Mar do Estado de São Paulo entre 500 e $1.000 \mathrm{~m}$ alt., florescendo durante o ano todo, principalmente de julho a outubro. No Núcleo Curucutu foi encontrada com frequência, sendo coletada com flores de maio a dezembro. A frutificação foi observada apenas uma vez, em novembro.

A espécie caracteriza-se por apresentar a corola variando do amarelo ao vermelho. Os espécimes observados possuem tricomas simples esparsos no pecíolo e na face abaxial do limbo, principalmente sobre a nervura central, não condizendo com a literatura consultada (Chautems 2003), na qual essas estruturas são glabras.

Nematanthus gregarius pode ser confundida com $N$. wettsteinii por apresentar, principalmente, lâmina foliar e corola compartilhando muitos caracteres, entretanto difere desta espécie por apresentar estruturas vegetativas e florais comparativamente maiores (lâmina foliar 1,2-3,2 × 0,8-1,6 cm e sépalas 10-15 $\times 4-6 \mathrm{~mm})$ e os lobos da corola concolores.

Outra espécie bastante semelhante é Nematanthus teixeiranus (Handro) Chautems, que pode ser 
diferenciada de $N$. gregarius por apresentar folhas pubescentes na face abaxial, sépalas membranáceas e pubérulas, alaranjadas na base e avermelhadas no ápice (Chautems 2003).

\subsection{Nematanthus maculatus (Fritsch) Wiehler,} Selbyana 5(1): 63.1978

Figura 1 i

Caule com entrenós 2,0-5,0 cm, cilíndricoachatado, pubérulo a glabrescente. Folhas anisófilas; pecíolo 4-32 mm compr., pubérulo; lâmina 3,8-12,5 × 1,5-6,0 cm, obovado-elíptica, base cuneada a obtusa, ápice acuminado, margem inteira, face adaxial glabra, verde, face abaxial pubérula, verde com mácula vinácea nitidamente delineada no centro, borda verde, 4-5 pares de nervuras secundárias evidentes. Flores 1 por axila, ressupinadas; pedicelo $0,6-1,7 \mathrm{~cm}$ compr., pubescente; sépalas 8-11 × 2-3 mm, cartáceas, base vinácea e ápice verde, pubescentes, lanceoladas, ápice obtuso a agudo, eretas a levemente revolutas, margem serreada; corola 2,0-3,6 cm compr., parte tubuloso-cilíndrica 1,5-2,0 cm compr., giba na porção superior, 0,8-0,9 × 0,8-0,9 cm, rosada a vinácea, hirsuta, lobos ca. $2 \mathrm{~mm}$ compr., discolores, amarelos, patentes; ovário 4-5 mm compr., pubescente, estilete 12-16 mm compr., glabro. Cápsula 7-17 × 3-8 mm, valvas vináceas, base esparsamente pubérula e ápice pubescente.

Material examinado: BRASIL. São PAULO: São Paulo, Trilha do Mirante, 14-V-1997, fl., N.S. Chukr 558 et al. (PMSP, UNISA); Epífita sobre Pinus, 15-V-1998, fl., L.C.Q.M.P. Sampaio 90 et al. (PMSP, UNISA); Trilha da Mata, 16-VII-2001, fl., C.M. Izumisawa 310 (PMSP); Trilha da Mata, 22-VI-2001, fl., M.A.S. Mayworm 210 \& R.J.F. Garcia (UNISA); Trilha da Mata, 14-VI-2004, fl., P. Affonso 664 et al. (UNISA); Trilha da Bica, 15-III-2006, fl., P. Affonso 923 et al. (UNISA); Trilha da Bica, 25-VI-2008, fl. e fr. P. Affonso 1074 et al. (UNISA); Trilha do Rio EmbuGuaçu, 29-VII-2009, fl., fr., P. Affonso 1148 et al. (UNISA); Trilha da Captação d'água, 29-X-2009, fr., P. Affonso 1173 et al. (UNISA).

Material adicional examinado: BRASIL. SÃo PAULO: Caraguatatuba, 3-XII-2000, fl., P. Fiaschi 492 (SPF); Itanhaém, restinga, 4-IV-1983, fl., A. Chautems $72 \&$ M. Peixoto (SP); Mongaguá, 4-IV-1983, fl., A. Chautems $73 \&$ M. Peixoto (SP); Picinguaba, Manguezal do Rio Picinguaba, fl., 2-VII-1998, M. Gomes-Neto 4 (SPSF, UNISA); São Paulo,
Parelheiros, área ajardinada, 19-IV-1995, fl., S.A.P. Godoy 475 (PMSP, SPF).

Nematanthus maculatus é endêmica do Brasil e possui distribuição nos Estados de São Paulo, Paraná e Santa Catarina (Chautems 2003, Araújo \& Chautems 2013), nas encostas da Serra do Mar entre a planície litorânea e $500 \mathrm{~m}$ de altitude florescendo entre março e dezembro (Chautems 2003). No Núcleo Curucutu foi encontrada com frequência no entorno da sede a $790 \mathrm{~m}$ de altitude, com flores em março e maio a julho, e frutos em julho e outubro.

Esta espécie é notável pela mácula vinácea na face abaxial das lâminas. Além disso, tem como caracteres diagnósticos as flores ressupinadas e as sépalas com a margem serreada.

Os materiais provenientes da área de estudo desta espécie que se encontravam depositados nos herbários estavam erroneamente identificados como Nematanthus fritschii Hoehne, com o qual N. maculatus é facilmente confundida devido à morfologia das lâminas, especialmente no que se refere à presença da mácula vinácea na face abaxial. Entretanto, N. maculatus é claramente distinta de Nematanthus fritschii pelo tamanho do pedicelo, 0,8-1,5 cm na primeira espécie e 2-10 cm na segunda, de acordo com Chautems (2003).

\subsection{Nematanthus wettsteinii (Fritsch) H.E. Moore,}

Baileya 19(1): 38. 1973.

Caule com entrenós 0,3-3,2 cm, cilíndrico, glabrescente. Folhas isófilas; pecíolo $1 \mathrm{~mm}$ compr., densamente pubescente; lâmina $0,8-1,7 \times 0,5-0,8 \mathrm{~cm}$, obovado-elíptica, base cuneada, ápice obtuso a agudo, margem inteira, face adaxial glabra, face abaxial pubérula, principalmente na nervura central, verde nas duas faces, borda verde, nervuras secundárias não evidentes. Flores 1 por axila, não ressupinadas; pedicelo 3-7 mm compr., pubescente na base e pubérulo no ápice; sépalas 2-3× ca. $1 \mathrm{~mm}$, verdes, membranáceas, pubérulas, lineares, ápice obtuso a agudo, eretas, margem inteira; corola 1,2-1,5 cm compr., parte tubulosa-cilíndrica ca. $3 \mathrm{~mm}$ compr., giba pronunciada na porção mediana superior, $0,6-0,7 \times 0,6-0,7 \mathrm{~cm}$, alaranjada, pubérula, lobos ca. $1 \mathrm{~mm}$ compr., discolores, amarelos, eretos; ovário 3-4 mm compr., pubescente com maior concentração no ápice, estilete 4-5 mm compr., glabro. Cápsula ca. $7 \times 4,5 \mathrm{~mm}$, valvas vermelhas, pubérula na base e pubescente no ápice.

Material examinado: BRASIL. São PaUlo: São Paulo, Trilha do Japonês, 11-VII-1999, fl., fr., M.A.S. Mayworm 124 b et al. (UNISA, PMSP). 
Material adicional examinado: BRASIL. São PAULO: São Paulo, Barra do Turvo, 14-II-1995, fl., fr., J.A. Zandoval 66 (SP); Ribeirão Grande, Parque Estadual Intervales, 16-IV-2003, fl., C. Urbanetz 28 (SPSF). Tapiraí, mata de encosta, rodovia SP 79, 900-950 m, 11-V-1994, fl., fr., R.M. Silva 890 et al. (PMSP, SPF).

Nematanthus wettsteinii é endêmica do Brasil, ocorrendo nos Estados do Paraná e São Paulo (Chautems 2003, Araújo \& Chautems 2013), entre 500 a $800 \mathrm{~m}$ de altitude, na Mata Atlântica. Floresce de abril a setembro, raramente em janeiro (Chautems 2003). No Núcleo Curucutu foi encontrada apenas uma vez, tratando-se de uma nova ocorrência para a área de estudo.

Nematanthus wettsteinii apresenta os lobos da corola discolores e estruturas vegetativas e florais comparativamente menores (lâmina foliar $0,8-1,7 \times 0,5-0,8 \mathrm{~cm}$ e sépalas $2-3 \times$ ca. $1 \mathrm{~mm})$ do que Nematanthus gregarius, a espécie mais próxima presente no Núcleo Curucutu.

4. Sinningia elatior (Kunth) Chautems. Candollea 45: 383. 1990.Figura $1 \mathrm{j}-\mathrm{k}$

Ervas ca. $75 \mathrm{~cm}$ alt., terrestres. Caule ereto, entrenós 2,8-7,5 cm, cilíndrico-achatado, pubescente, com tricomas simples; sistema subterrâneo tuberoso perene. Folhas levemente anisófilas, 3-verticiladas, pecioladas; pecíolo 2-4 mm compr., pubescente; lâmina 3-8,7 × 1-3,4 cm, elíptica a elíptico-ovada, cartácea, base obtusa, ápice obtuso, margem crenada, pubescente e verde em ambas as faces, borda-verde, 5-7 nervuras secundárias evidentes. Inflorescência terminal, pseudoracemo; flores não ressupinadas, (1-)2-4 nas axilas de bractéolas 3-verticiladas, 0,4-1,1 cm compr., lanceoladas a triangulares; pedúnculo ausente; pedicelo 15-18 mm compr., pubescente; sépalas 6-8 × 2-3 mm, cartáceas, verdes, pubescentes, triangulares, ápice agudo a acuminado, eretas, margem inteira; corola 2,4-4 cm compr., bilabiada, tubulosoventricosa, parte tubuloso-cilíndrica 2,2-3,1 cm compr., giba pouco pronunciada na porção basal do tubo, giba ca. $0,4 \times 0,1 \mathrm{~cm}$, vermelha, pubescente, lobos 3-6 mm compr., dorsais unidos, concolores, patentes; estames 4, filetes com tricomas simples esparsos, anteras unidas em retângulo, exsertas, rimosas; nectário formado por 5 glândulas, 2 dorsais maiores e unidas; ovário ca. $3 \mathrm{~mm}$ compr., súpero, pubescente, estilete ca. $3 \mathrm{~cm}$ compr., pubescente, estigma exserto. Cápsula seca loculicida, 13-16 × 4-6 mm, 2-valvar, castanha, ovóidecônica, pubescente, base do estilete não persistente na maturidade; sementes elípticas, castanhas, estriadas.
Material examinado: BRASIL. São PAULO: São Paulo, Trilha do banquinho, 23-XI-2000, fl., M.A.S. Mayworm 189 et al. (PMSP, UNISA). Trilha do rio Embu-Guaçu, 1-II-2001, fl., fr., P. Affonso 490 et al. (PMSP, UNISA).

Material adicional examinado: ARGENTINA. Corrientes: San Miguel, 19-XII-2002, fl., fr., M.M. Sosa 82 (SP). BRASIL. GoiÁs: Paraúna, 25-I-1995, fl., F. de Barros 2197 (SP). Mato Grosso do Sul: Brasilândia, Estrada do Porto João André-Brasilândia, 26-XI-1992, E.L.M. Catharino 1825 et al. (SP). MinAS GeraIs: Caldas, 10-I-1919, fl., F.C. Hoehne 2760 (SP). PARANÁ: Terra Rica, 8-I-1991, fl., fr., F. de Barros 2129 (SP). São Paulo: Brotas, Vila de São Sebastião da Serra, 27-I-2007, fl., S.A. Nicolau 3186 et al. (SP); Itapeva, Estação Experimental, 29-IX-2010, fl., C.R. Lima et al. 310 (SPSF); Itararé, Estrada Itararé-Itapeva, 14-XI-1994, fl., V.C. Souza 7250 et al. (PMSP); São Paulo, São Paulo, Marsilac, 2-XII-2004, fl., P. Affonso 755 et al. (UNISA).

O gênero Sinningia tem distribuição neotropical com 67 espécies ocorrendo no Brasil, das quais 55 são endêmicas. O Estado de São Paulo abriga 25 espécies (Araújo \& Chautems 2013).

Sinningia elatior tem ampla distribuição, ocorrendo em vários países da América do Sul (Chautems 2003), e no Brasil, ocorre no Distrito Federal e nos Estados do Amazonas, Tocantins, Goiás, Mato Grosso, Mato Grosso do Sul, e da Bahia até o Rio Grande do Sul. É a espécie mais amplamente distribuída, sendo encontrada na Amazônia, Caatinga, Cerrado e na Mata Atlântica (Araújo \& Chautems, 2013), com flores de outubro a março (Chautems 2003).

Trata-se de uma espécie rara no Núcleo do Curucutu, conhecida apenas por dois exemplares que foram encontrados em formação campestre, diferindo das demais espécies estudadas que habitam os ambientes florestais. Floresceu em novembro e fevereiro, e frutificou em fevereiro.

Sinningia elatior é claramente distinta das demais espécies estudadas por ser a única a apresentar tubérculo, as folhas 3-verticiladas e a inflorescência em pseudoracemo.

\section{Agradecimentos}

Ao Instituto Florestal, pela autorização para realização deste trabalho no Núcleo Curucutu. Aos Curadores dos herbários visitados, PMSP, SP, SPF e SPSF. À Universidade de Santo Amaro, pelo apoio financeiro. 


\section{Literatura citada}

Araujo, A.O. \& Chautems, A. 2013. Gesneriaceae. In: Lista de Espécies da Flora do Brasil. Jardim Botânico do Rio de Janeiro. Disponível em http//floradobrasil. jbrj.gov.br/jabot/FB119 (acesso em IV-2013).

Araujo, A.O., Souza, V.C. \& Chautems, A. 2005. Gesneriaceae da Cadeia do Espinhaço de Minas Gerais, Brasil. Revista Brasileira de Botânica 28: 109 -135.

Chautems, A. 1991. A família Gesneriaceae na região cacaueira do Brasil. Revista Brasileira de Botânica 14: 51-59.

Chautems, A. 2000. Gesneriaceae. In: Melo, M.M. da R.F. et al. (eds.). Flora Fanerogâmica da Ilha do Cardoso. Instituto de Botânica, São Paulo, v.7, pp. 53-69.

Chautems, A. 2003. Gesneriaceae. In: Wanderley, M.G.L., Shepherd, G.J., Giulietti, A.M., Melhem, T.S. Flora Fanerogâmica do Estado de São Paulo. Instituto de Botânica, FAPESP, São Paulo, v.3, pp. 75-103.

Clark, J.L., Funke, M.M., Duffy, A.M. \& Smith, J.F. 2012. Phylogeny of a neotropical clade in the Gesneriaceae: more tales of convergent evolution. International Journal of Plant Sciences 173: 894-916.

Fidalgo, O. \& Bononi, V.L.R. 1989. Técnicas de coleta, preservação e herborização de material botânico. Instituto de Botânica, São Paulo.

Garcia, R.J.F. \& Pirani, J.R. 2005. Análise florística, ecológica e fitogeográfica do Núcleo Curucutu, Parque Estadual da Serra do Mar (São Paulo, SP), com ênfase nos campos junto à crista da Serra do Mar. Hoehnea 32: $1-48$.

Gonçalves, E.G. \& Lorenzi, H. 2007. Organografia e dicionário ilustrado de morfologia das plantas. Instituto Plantarum de Estudos da Flora, Nova Odessa.

Hanstein, J. 1864. Gesneriaceae. In: Martius, C.F.P., Eichler, A.W. \& Urban, I. (eds.) Flora Brasiliensis. Lipsidae, Monachii, v.8, part 1, fasc. 36, pp. 341-428.

Harris, J.G. \& Harris, M.W. 1994. Plant identification terminology: an illustrated glossary. Spring Lake Publishing, Utah.

Instituto Florestal - I.F. 2013. Parque Estadual da Serra do Mar - Núcleo Curucutu. Disponível em http/www. iflorestal.sp.gov.br/unidades_conservacao/informacoes. asp? $\operatorname{cod}=21>$ (acesso em I-2013).

Lopes, T.T.C., Andreata, R.H.P. \& Chautems, A. 2007. Distribuição e conservação do gênero Besleria L. (Gesneriaceae) no Brasil: dados preliminares. Revista Brasileira de Biociências 5: 876-878.
Perret, M., Chautems, A., Araujo, A.O. \& Salamin, N. 2013. Temporal and spatial origin of Gesneriaceae in the New Worl inferred from plastid DNA sequences. Botanical Journal of the Linnean Society 171: 61-79.

Pscheidt, A.C. \& Affonso, P. 2008. Levantamento da família Gentianaceae Juss. no Núcleo Curucutu, Parque Estadual da Serra do Mar, São Paulo. Revista do Instituto Florestal 20: 147-153.

Rodrigues Lima, A.A. \& Affonso, P. 2010. Levantamento de Leandra Raddi no Núcleo Curucutu, Parque Estadual da Serra do Mar, São Paulo. Revista do Instituto Florestal 22: 15-32.

Rosa, A.R. \& Affonso, P. 2009. Levantamento do gênero Oncidium Sw. sensu lato (Orchidaceae) no Núcleo Curucutu, Parque Estadual da Serra do Mar, São Paulo. Revista do Instituto Florestal 21: 55-62.

Silva, C.V. \& Affonso, P. 2005. Levantamento de Tibouchina Aubl. (Melastomataceae) no Parque Estadual da Serra do Mar, Núcleo Curucutu, São Paulo. Revista do Instituto Florestal 17: 195-206.

Smith, J.F. 1996. Tribal relationships within Gesneriaceae: a cladistic analysis of morphological data. Systematic Botany 21: 497-513.

Smith, J.F., Wolfram, J.C., Brown, K.D., Carrol, C.L. \& Denton, D.S. 1997. Tribal relationships in the Gesneriaceae: evidence from DNA sequences of the chloroplast gene $n d h F$. Annals of the Missouri Botanical Garden 84: 50-66.

Souza, V.C. \& Lorenzi H. 2012. Botânica Sistemática: guia Ilustrado para identificação das famílias Fanerógamas nativas e exóticas no Brasil, baseado em APG III. $3^{\text {a }}$ ed. Instituto Plantarum de Estudos da Flora, Nova Odessa.

Takeuchi, C. \& Affonso, P. 2009. Levantamento de Ericaceae Juss. no Núcleo Curucutu, Parque Estadual da Serra do Mar, São Paulo. Revista do Instituto Florestal 21: 131-138.

Takeuchi, C., Affonso, P. \& Chukr, N.S. 2008. Levantamento de Iridaceae Juss. no Núcleo Curucutu, Parque Estadual da Serra do Mar, São Paulo. Revista do Instituto Florestal 20: 51-63.

Thiers, B. (continuamente atualizado). Index herbariorium: A global directory of publish herbaria and associated staff. New York Botanical Garden's Virtual Herbarium. Disponível em http// sweetgum.nybg.org/ih (acesso em II-2013).

Weber, A. \& Skog, L.E. 2007 (em diante). The genera of Gesneriaceae. Basic information with illustration of selected species. 2 ed. Disponível em http://www. genera-gesneriaceae.at/ (acesso em IV-2013). 